\title{
Validation and analysis of MOPITT CO observations of the Amazon Basin
}

\author{
M. N. Deeter ${ }^{1}$, S. Martínez-Alonso ${ }^{1}$, L. V. Gatti ${ }^{2}$, M. Gloor ${ }^{3}$, J. B. Miller ${ }^{4,5}$, L. G. Domingues ${ }^{2}$, and C. S. C. Correia $^{2}$ \\ ${ }^{1}$ Atmospheric Chemistry Observations and Modeling Laboratory, National Center for \\ Atmospheric Research, Boulder, CO, USA \\ ${ }^{2}$ Instituto de Pesquisas Energéticas e Nucleares (IPEN)-Comissao Nacional de Energia Nuclear (CNEN)-Atmospheric \\ Chemistry Laboratory, 2242 Avenida Professor Lineu Prestes, Cidade Universitaria, Sao Paulo CEP 05508-000, Brazil \\ ${ }^{3}$ School of Geography, University of Leeds, Woodhouse Lane, Leeds LS9 2JT, UK \\ ${ }^{4}$ Global Monitoring Division, Earth System Research Laboratory, National Oceanic and Atmospheric Administration, \\ 325 Broadway, Boulder, CO 80305, USA \\ ${ }^{5}$ Cooperative Institute for Research in Environmental Sciences (CIRES), University of Colorado, Boulder, CO 80309, USA
}

Correspondence to: M. N. Deeter (mnd@ucar.edu)

Received: 20 April 2016 - Published in Atmos. Meas. Tech. Discuss.: 26 April 2016

Revised: 29 July 2016 - Accepted: 2 August 2016 - Published: 23 August 2016

\begin{abstract}
We analyze satellite retrievals of carbon monoxide from the MOPITT (Measurements of Pollution in the Troposphere) instrument over the Amazon Basin, focusing on the MOPITT Version 6 "multispectral" retrieval product (exploiting both thermal-infrared and near-infrared channels). Validation results based on in situ vertical profiles measured between 2010 and 2013 are presented for four sites in the Amazon Basin. Results indicate a significant negative bias in retrieved lower-tropospheric $\mathrm{CO}$ concentrations. The possible influence of smoke aerosol as a source of retrieval bias is investigated using collocated Aerosol Robotic Network (AERONET) aerosol optical depth (AOD) measurements at two sites but does not appear to be significant. Finally, we exploit the MOPITT record to analyze both the mean annual cycle and the interannual variability of $\mathrm{CO}$ over the Amazon Basin since 2002.
\end{abstract}

\section{Introduction}

Seasonal biomass burning in the Amazon Basin profoundly affects atmospheric composition, both regionally and globally. Amazonian emissions include a wide range of trace gases and aerosols (Andreae et al., 2001, 2012). With respect to climate change, future emissions from the Amazon Basin could play a significant role in determining the trajectory of global temperatures (Gullison et al., 2007). Biomass burning emissions in Amazonia are the result of deforestation practices (Malhi et al., 2008) and understory fires, i.e., accidental fires that spread into intact rainforest (Cochrane, 2003). Accurately quantifying emissions from Amazonia from all sources will be increasingly important as policies are enacted to reduce emissions of greenhouse gases associated with deforestation and degradation (Miles and Kapos, 2008; Aragão and Shimabukuro, 2010).

Coupled with satellite observations of active fires, burnedarea estimates are used as the basis of published "bottom-up" biomass burning emissions inventories, such as the Global Fire Emissions Database (GFED) (Giglio et al., 2013) and the Fire INventory from NCAR (FINN) (Wiedinmyer et al., 2011). Such methods for estimating emissions of biomass burning products (i.e., surface fluxes of individual species) are characterized by large uncertainties. Alternatively, emissions of some species may be quantified using atmospheric observations in "top-down" approaches. Inverse modeling methods combine atmospheric observations with chemical transport models to relate emissions to atmospheric concentrations (Arellano et al., 2006; Fortems-Cheiney et al., 2011; Hooghiemstra et al., 2012). Satellite observations are often employed in inverse modeling because of their unique ability to monitor atmospheric composition over large regions 
with relatively high (weekly or better) sampling frequency and spatial density.

However, the optimal use of satellite retrievals for tracegas concentrations in inverse modeling systems requires that (1) the vertical sensitivity of the retrieved profiles and the inclusion of a priori information be properly represented (Kopacz et al., 2010) and (2) any retrieval biases be compensated (Hooghiemstra et al., 2012). The geographical variability of retrieval properties (i.e., vertical sensitivity and retrieval biases) for some satellite products highlights the importance of thoroughly analyzing retrieval performance prior to the use of such products in inverse modeling studies.

In the following, we analyze retrievals of carbon monoxide (CO) from the MOPITT (Measurements of Pollution in the Troposphere) satellite instrument (Drummond et al., 2010; Deeter et al., 2014) to investigate the utility of MOPITT products for estimating emissions from the Amazon Basin. We first characterize the vertical sensitivity of MOPITT CO retrieval products over Amazonia through an analysis of the MOPITT retrieval averaging kernels. Next, we present new MOPITT validation results by exploiting a set of in situ CO profiles measured from aircraft at four sites in Amazonia between 2010 and 2013. The influence of smoke aerosols on MOPITT retrievals is then studied by comparing MOPITT retrieval biases with ground-based aerosol optical depth measurements from two Amazonian sites in the Aerosol Robotic Network (AERONET). Finally, we present and interpret the recent history of $\mathrm{CO}$ concentrations over Amazonia (2002-2015) based on the MOPITT record.

\section{Satellite retrieval properties}

\subsection{MOPITT retrieval products}

MOPITT is a gas-filter correlation radiometer instrument on the NASA Terra polar-orbiting satellite. MOPITT observations enable retrievals of tropospheric vertical profiles and total column amounts of carbon monoxide (CO) based on simultaneous thermal-infrared (TIR) and near-infrared (NIR) observations (Drummond et al., 2010). The MOPITT instrument has been operating nearly continuously since 2000, providing the longest available satellite record for $\mathrm{CO}$. MOPITT retrieval products have progressively improved as the result of accumulated knowledge regarding the instrument, forward-modeling methods, and geophysical variables (Worden et al., 2014). Results presented in this manuscript exploit the MOPITT Version 6 (V6) TIR-only and "multispectral" TIR-NIR products (Deeter et al., 2014). The TIR-NIR product offers the greatest vertical resolution, and particularly the greatest sensitivity to $\mathrm{CO}$ in the lower troposphere. However, the improved sensitivity of this product is only achieved in daytime MOPITT observations over land. The TIR-only product offers the highest temporal stability and similar performance in variable observing situations (day and night, land and ocean).

Typically, TIR-based satellite retrieval products (including those from the AIRS, TES, and IASI instruments) exhibit relatively low sensitivity to CO concentrations near the earth's surface except in situations with high thermal contrast (Deeter et al., 2007). Thus, CO molecules emitted at the surface may only become "visible" to TIR-based instruments after they ascend into the free troposphere through vertical mixing and may be advected large distances horizontally. The combined effects of instrumental vertical resolution and atmospheric dynamics thus limit both the spatial and temporal resolution of estimated $\mathrm{CO}$ emissions based on inverse modeling. Similar limitations affect the estimation of $\mathrm{CO}_{2}$ emissions using TIR satellite observations (Chevallier et al., 2005). To maximize the sensitivity to near-surface $\mathrm{CO}$, the MOPITT instrument uniquely incorporates both TIR and NIR gas correlation radiometers. For daytime observations over land, the added information provided by the NIR channels can substantially enhance the sensitivity to CO near the surface compared to TIR-only retrievals (Worden et al., 2010). This enhancement is illustrated below in an analysis of the MOPITT averaging kernels.

An example of the difference in TIR-only and TIR-NIR retrievals of surface-level $\mathrm{CO}$ concentrations for a single MOPITT overpass of the western Amazon Basin on 17 September 2010 is shown in Fig. 1. The selected date represents a day approximately in the middle of the dry season when fire emissions affect much of the southern Amazon Basin. Maps of the CO a priori, V6 TIR-only, and V6 TIR-NIR products are presented along with a map of gridded Moderate Resolution Imaging Spectroradiometer (MODIS) Aqua fire counts for the 8-day period from 15 to 22 September 2010. Fires during this period were observed in southwestern Brazil and north-central Bolivia. As described in the following section, the a priori represents the background (or default) $\mathrm{CO}$ concentration for the retrieval algorithm. The a priori map indicates the highest surface-level $\mathrm{CO}$ concentrations in northern Bolivia, with $\mathrm{CO}$ concentrations decreasing towards the north, west, and south. V6 TIR-only surface-level retrievals exhibit a pattern very similar to the a priori but with somewhat lower $\mathrm{CO}$ concentrations in Peru and southwestern Bolivia, and somewhat higher $\mathrm{CO}$ concentrations in Brazil. In contrast, the map of V6 TIR-NIR surface-level retrievals reveals a visibly different pattern compared to the a priori, with the region of highest $\mathrm{CO}$ concentrations including much of western Brazil.

\subsection{Averaging kernel variability}

The MOPITT retrieval algorithm relies on optimal estimation (Rodgers, 2000; Pan et al., 1998; Deeter et al., 2003, 2014). Retrieved CO profiles are reported on a 10-level pressure grid; the reported retrieval for each level indicates the mean volume mixing ratio (VMR) in the layer immediately 

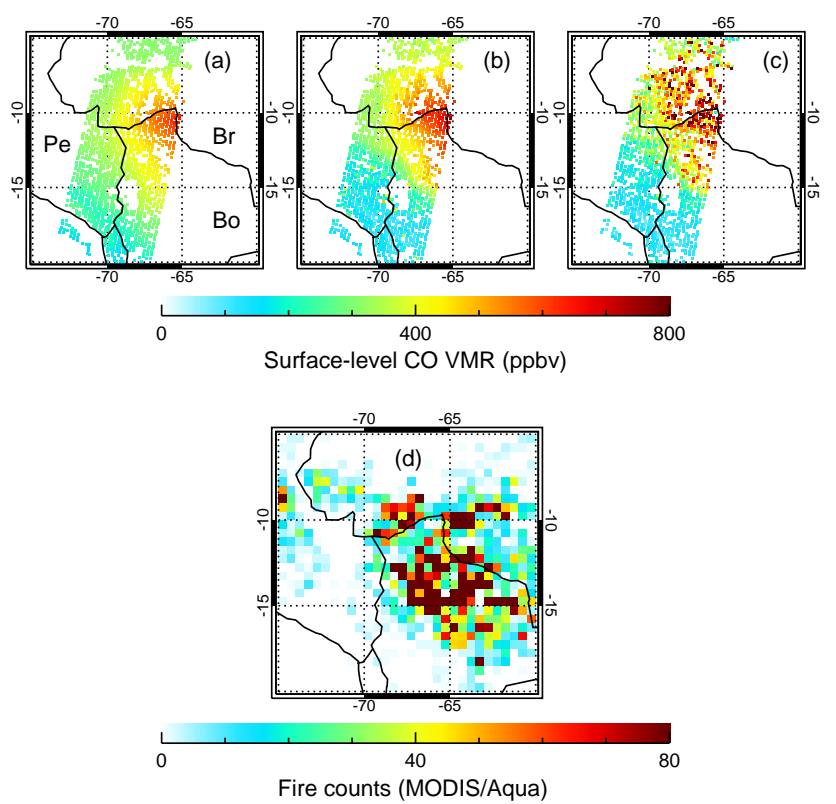

Figure 1. Comparison of (a) climatological MOPITT surface-level $\mathrm{CO}$ a priori concentrations, (b) V6 TIR-only retrieved surface-level $\mathrm{CO}$, and (c) V6 TIR-NIR retrieved surface-level CO for a daytime MOPITT overpass of the western Amazon Basin on 17 September 2010. Country abbreviations in (a) include "Pe" for Peru, "Br" for Brazil, and "Bo" for Bolivia. Gridded fire counts based on MODIS Aqua observations for the 8-day period from 15 to 22 September 2010 are shown in (d). The map of V6 TIR-NIR surface-level retrievals reveals a region of high $\mathrm{CO}$ concentrations over much of western Brazil, whereas the V6 TIR-only retrievals tend more towards the a priori.

above that level (Deeter et al., 2013). Internally, CO concentrations in the retrieval state vector are represented in terms of the logarithm of the VMR. For each retrieved $\log (\mathrm{VMR})$ profile resulting from a single MOPITT observation, the retrieval averaging kernel matrix $\mathbf{A}$ is produced simultaneously and is provided as a diagnostic in the MOPITT Level 2 and Level 3 data files. A characterizes the sensitivity of the retrieved $\log (\mathrm{VMR})$ profile to both the true $\log (\mathrm{VMR})$ profile $x_{\text {true }}$ and a priori $\log (\mathrm{VMR})$ profile $x_{\mathrm{a}}$ through the relation

$x_{r t v}=x_{\mathrm{a}}+\mathbf{A}\left(x_{\text {true }}-x_{\mathrm{a}}\right)$.

In the V6 retrieval algorithm, $x_{\mathrm{a}}$ profiles vary seasonally and geographically according to a multi-year model-based CO climatology (Lamarque et al., 2012; Deeter et al., 2014). This global climatology was produced from a 10-year Community Atmosphere Model with Chemistry (CAM-chem) run (2000-2009) and incorporated $\mathrm{CO}$ emissions from the GFED2 emissions database (van der Werf et al., 2006). The climatology is gridded at $1^{\circ}$ (latitude and longitude) horizontal resolution and monthly temporal resolution. Spatial and temporal interpolation are used to generate a priori values at a specific location and day. Each row of $\mathbf{A}$ corresponds to one level in the retrieved profile, whereas each column of A corresponds to one level in the "true" CO profile. Each element of $\mathbf{A}$ describes the sensitivity of the $\log (\mathrm{VMR})$ value at one level in the retrieved profile to the $\log (\mathrm{VMR})$ value at one level in the true profile. A depends on the weighting function matrix $\mathbf{K}$, a priori covariance matrix $\mathbf{C}_{\mathrm{a}}$, and observation error covariance matrix $\mathbf{C}_{\mathrm{e}}$ according to the relation (Rodgers, 2000)

$\mathbf{A}=\left(\mathbf{K}^{T} \mathbf{C}_{\mathrm{e}}^{-1} \mathbf{K}+\mathbf{C}_{\mathrm{a}}^{-1}\right)^{-1} \mathbf{K}^{T} \mathbf{C}_{\mathrm{e}}^{-1} \mathbf{K}$.

Elements of $\mathbf{K}$ (also known as the "Jacobian" matrix) describe the vertical sensitivity of the measured radiances to applied perturbations to individual levels in the $\mathrm{CO}$ vertical profile. As implied by Eq. (2), the features of $\mathbf{K}$ largely dictate the features of A. MOPITT averaging kernels are strongly sensitive to both instrumental variables and geophysical parameters (Worden et al., 2013; Deeter et al., 2015).

Analysis of the averaging kernels enables an understanding of the vertical resolution and information content of the MOPITT retrieved profiles. The width of each averaging kernel provides a measure of the vertical resolution associated with a specific level of the retrieved profile, whereas the area under the averaging kernel (i.e., the sum of the elements) indicates the integrated sensitivity of the retrieval to the true profile (Rodgers, 2000). Averaging kernels characterized by a small area (e.g., much less than one) indicate a retrieval level heavily weighted by the a priori. The trace of $\mathbf{A}$ (i.e., the sum of the diagonal elements) defines the "degrees of freedom for signal", or DFS, and is often interpreted as the number of independent pieces of information in the retrieval from the measurement. Properties of the averaging kernel for the retrieved surface-level $\mathrm{CO}$ concentration are particularly important since the primary sources of $\mathrm{CO}$ are located at the surface, and tropospheric concentrations of $\mathrm{CO}$ often peak at or near the surface.

\subsection{Averaging kernel comparisons}

Mean MOPITT averaging kernels for a region of the western Amazon Basin of $10-5^{\circ} \mathrm{S}$ and $70-65^{\circ} \mathrm{W}$ for a daytime overpass of the MOPITT instrument on 1 July 2010 are shown in Fig. 2. Mean averaging kernels for the TIR-only product and the TIR-NIR product are both presented. MOPITT averaging kernels for another daytime overpass of the same region on 17 September 2010 are presented in Fig. 3. Whereas the date of the first overpass corresponds to the beginning of the dry season when $\mathrm{CO}$ concentrations are near the minimum of the annual cycle, the second overpass represents a period in the middle of the Amazon dry season characterized by high $\mathrm{CO}$ values across most of the Amazon Basin (Edwards et al., 2006). For the selected region, mean retrieved surfacelevel CO concentrations on 1 July for the TIR-only and TIRNIR products were 144 and $146 \mathrm{ppbv}$, which is significantly less than the regional a priori value of $202 \mathrm{ppbv}$. Corresponding TIR-only and TIR-NIR values for 17 September were 

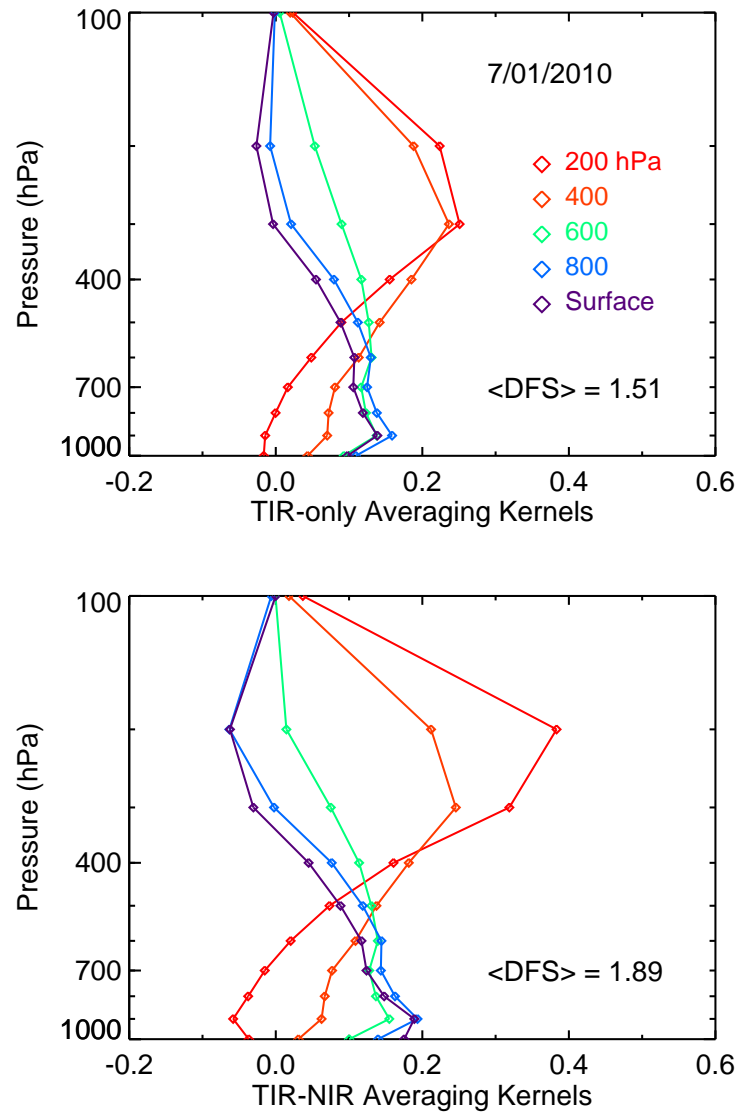

Figure 2. Comparison of mean retrieval averaging kernels for the MOPITT Version 6 TIR-only (top panel) and TIR-NIR (bottom panel) products for the western Amazon Basin (within 10-5 $5^{\circ} \mathrm{S}, 70$ $65^{\circ} \mathrm{W}$ ) on 1 July 2010 . For clarity, only the averaging kernels for alternating levels in the MOPITT retrieval grid (i.e., surface, $800 \mathrm{hPa}$, $600 \mathrm{hPa}$, etc.) are actually plotted.

431 and $512 \mathrm{ppbv}$, in comparison with an a priori value of 380 ppbv.

Mean averaging kernels for the TIR-only product for the high-CO overpass on 17 September 2010 (depicted in the top panel of Fig. 3) are considered first. For the selected scene, the mean TIR-only surface-level averaging kernel peaks at $800 \mathrm{hPa}$ and decreases sharply at the surface, revealing that the TIR-only surface-level retrievals exhibit poor sensitivity to $\mathrm{CO}$ at the surface. Also, the strong similarity in the shape of the surface-level and $800 \mathrm{hPa}$ averaging kernels illustrates the lack of independent information in the retrieved profile at these two levels. In contrast, for the TIR-NIR averaging kernels shown in the bottom panel of Fig. 3, the mean surface-level averaging kernel peaks at the surface and rapidly decreases at higher levels. Based on the full width at half maximum of this averaging kernel, the sensitivity of the TIR-NIR surface-level retrieval is dominated by the layer between the surface and about $800 \mathrm{hPa}$. Moreover, it is clear from the TIR-NIR averaging kernels that the retrieved con-
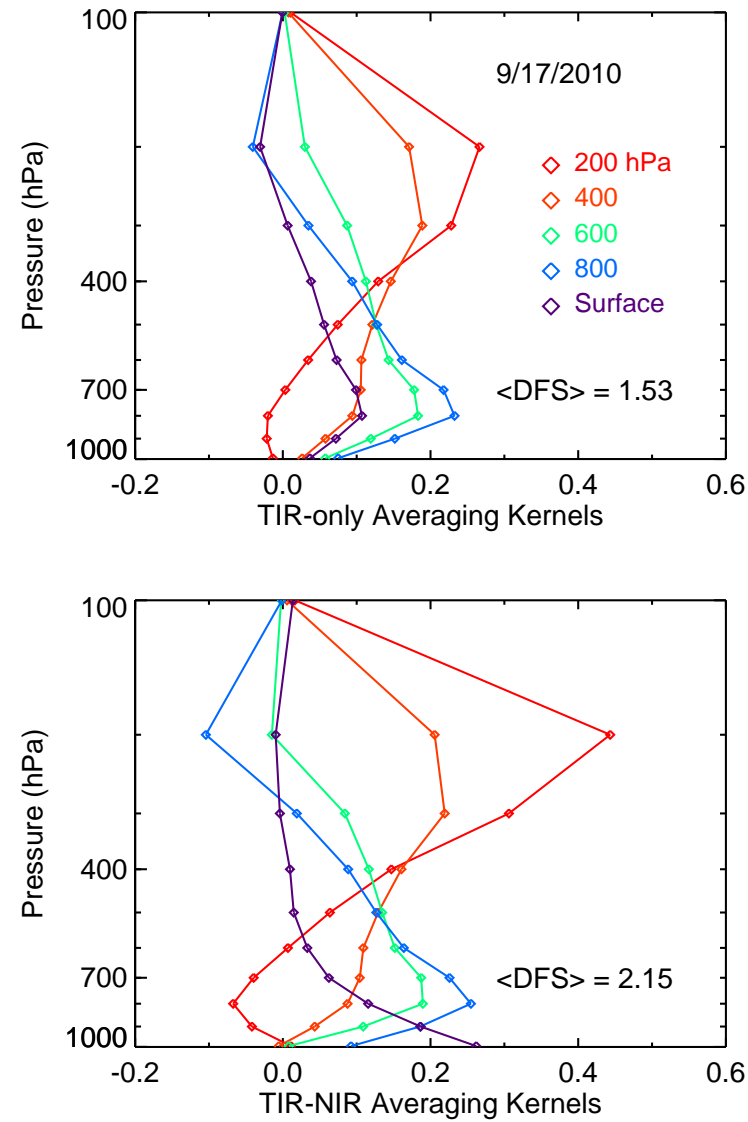

Figure 3. Comparison of mean retrieval averaging kernels for the MOPITT Version 6 TIR-only (top panel) and TIR-NIR (bottom panel) products for the western Amazon Basin on 17 September 2010.

centrations at the surface and at $800 \mathrm{hPa}$ contain independent information with respect to the $\mathrm{CO}$ profile. This enhancement in the retrieval information content is also consistent with the higher mean DFS value observed for the TIR-NIR retrievals (2.15) compared to the TIR-only retrievals (1.53).

Differences in the mean retrieval averaging kernels for 1 July and 17 September are expected as the result of the large difference in mean $\mathrm{CO}$ concentrations over the Amazon Basin for those two dates (Deeter et al., 2015). Increasing $\mathrm{CO}$ concentrations tend to strengthen the weighting functions for both the TIR and NIR channels, which affects characteristics of the averaging kernels. For the TIR-only product, this effect most severely impacts the $800 \mathrm{hPa}$ retrieval level. Both the width and peak value of the $800 \mathrm{hPa}$ averaging kernel are significantly degraded on 1 July. Comparing Figs. 2 and 3, the TIR-NIR surface-level averaging kernel on 1 July (shown in Fig. 2) peaks at a higher altitude and is substantially broader than for 17 September (Fig. 3). For characterizing $\mathrm{CO}$ concentrations in the lower troposphere, these results demonstrate that the MOPITT TIR-NIR product yields more information as $\mathrm{CO}$ concentrations increase. 


\section{Validation}

Retrieval validation involves the rigorous analysis of differences between retrieval products and independent measurements with well-characterized uncertainties. MOPITT retrievals have been validated with a variety of in situ datasets from which $\mathrm{CO}$ vertical profiles have been produced (Emmons et al., 2009; Deeter et al., 2014). For validating optimal estimation-based retrievals, the standard measure of retrieval error excludes the known smoothing effect of the retrieval process (as represented by the averaging kernel matrix) and the dependence on the a priori profile. Thus, rather than direct comparisons of retrieval products with in situ data, validation involves comparisons of retrieved profiles with simulated profiles calculated according to Eq. (1). For such comparisons, $\mathbf{A}$ and $x_{\mathrm{a}}$ are extracted from the MOPITT Level 2 data files and then applied to the $x_{\text {true }}$ profile which is based on the in situ data.

Because of the variety of sources of retrieval error, and the geographical and temporal variability of such errors, validation of the MOPITT CO product is an ongoing activity. Below, we present validation results for MOPITT retrieval products for the Amazon Basin for the first time. At least two potential challenges for MOPITT retrievals occur in this region during the biomass burning season. First, extreme $\mathrm{CO}$ concentrations could conceivably exceed the valid range of $\mathrm{CO}$ concentrations for the MOPITT radiative transfer model. This was found to be an issue for the MOPITT Version 3 product, which was addressed in the development of the Version 4 product (Deeter et al., 2010). Second, the effects of highly concentrated smoke aerosols could also degrade the quality of MOPITT retrievals. This topic is addressed in Sect. 3.3.

\subsection{Review of V6 validation results}

Validation results for the MOPITT V6 product were previously reported in Deeter et al. (2014). Those results were based on in situ profiles acquired during the HIPPO (HIAPER Pole-to-Pole Observations) field campaign (20092011) and through a long-term NOAA monitoring program mostly over North America. One significant finding from the HIPPO validation results was the apparent latitude dependence of observed retrieval biases in the V6 TIR-only product. For example, for the $800 \mathrm{hPa}$ retrieval level, there appeared to be a significant negative bias in the tropics which was absent in midlatitude and polar regions. The underlying cause of the observed latitude dependence of the bias has not been explained. Moreover, since nearly all HIPPO flights were over the open ocean, it is unclear if the observed latitude dependence would be expected over land scenes as well as ocean scenes.

\subsection{Aircraft-based in situ CO measurements in the Amazon}

Below, we exploit a set of in situ $\mathrm{CO}$ vertical profiles derived from a trace-gas sampling program over the Amazon Basin that began in 2010 (Gatti et al., 2014). Profiles are based on air samples acquired approximately biweekly from aircraft at four sites: Alta Floresta (ALF, $9^{\circ} \mathrm{S}, 57^{\circ} \mathrm{W}$ ), Rio Branco (RBA, $\left.9^{\circ} \mathrm{S}, 68^{\circ} \mathrm{W}\right)$, Tabatinga (TAB, $\left.6^{\circ} \mathrm{S}, 60^{\circ} \mathrm{W}\right)$, and Santarém (SAN, $3^{\circ} \mathrm{S}, 55^{\circ} \mathrm{W}$ ). The primary objective of the program is to observe and analyze the state, changes, and climate sensitivity of the Amazon carbon pools. In addition to $\mathrm{CO}$, concentrations of $\mathrm{CO}_{2}, \mathrm{CH}_{4}, \mathrm{~N}_{2} \mathrm{O}$, and $\mathrm{SF}_{6}$ are also measured for each air sample. Precision and accuracy of the in situ CO dry-air mole fraction (DMF) measurements are reported to be less than $1 \mathrm{ppb}$ (http://www.esrl.noaa.gov/gmd/ ccgg/aircraft/qc.html). The wide geographical distribution of the four sites permits the compositional analysis of airmasses as they first enter the Amazon Basin and as they become progressively affected by regional biomass burning emissions.

For most flights, the maximum sampling altitude attained by the aircraft flying over the Amazon Basin was approximately $4.4 \mathrm{~km}$, corresponding to a pressure of about $580 \mathrm{hPa}$. This altitude is substantially less than the altitude required to produce a complete 10-level vertical profile (from the surface to $100 \mathrm{hPa}$ ) suitable for MOPITT validation. Aircraft measurements of CO DMF were transformed into MOPITT VMR "validation profiles" in a process requiring several steps and two distinct pressure grids. First, in situ data for each profile were interpolated onto the standard 35-level fine grid used internally in the MOPITT retrieval algorithm (Edwards et al., 1999). Since this step is limited to grid levels only up to $600 \mathrm{hPa}$, the interpolated DMF value at $600 \mathrm{hPa}$ was extended vertically up to $250 \mathrm{hPa}$. In situ DMF values were then converted to moist-air VMR values using water vapor mixing ratios included in the CAM-chem-based climatology described above (Lamarque et al., 2012). Maximum differences between CO DMF and VMR values were about $3 \%$; differences generally peak at the surface. For levels in the fine grid at and above $100 \mathrm{hPa}$ (the approximate altitude of the tropical tropopause), CO VMR values were taken from the CAM-chem climatology. VMR values for grid between 250 and $100 \mathrm{hPa}$ were obtained by interpolation. Finally, resulting fine-grid VMR validation profiles were regridded into coarse 10-level validation profiles (for consistency with the actual MOPITT retrieval grid) by averaging the fine-grid VMR values in the layers immediately above the corresponding levels in the retrieval grid (Deeter et al., 2013).

The lack of in situ data above $580 \mathrm{hPa}$ precludes the use of these profiles for validating MOPITT retrievals of uppertropospheric $\mathrm{CO}$ concentrations. However, inspection of the MOPITT averaging kernels in Figs. 2 and 3 indicates that $\mathrm{CO}$ retrievals for the lower troposphere are only weakly sensitive to the actual $\mathrm{CO}$ concentrations at $500 \mathrm{hPa}$ and above. 

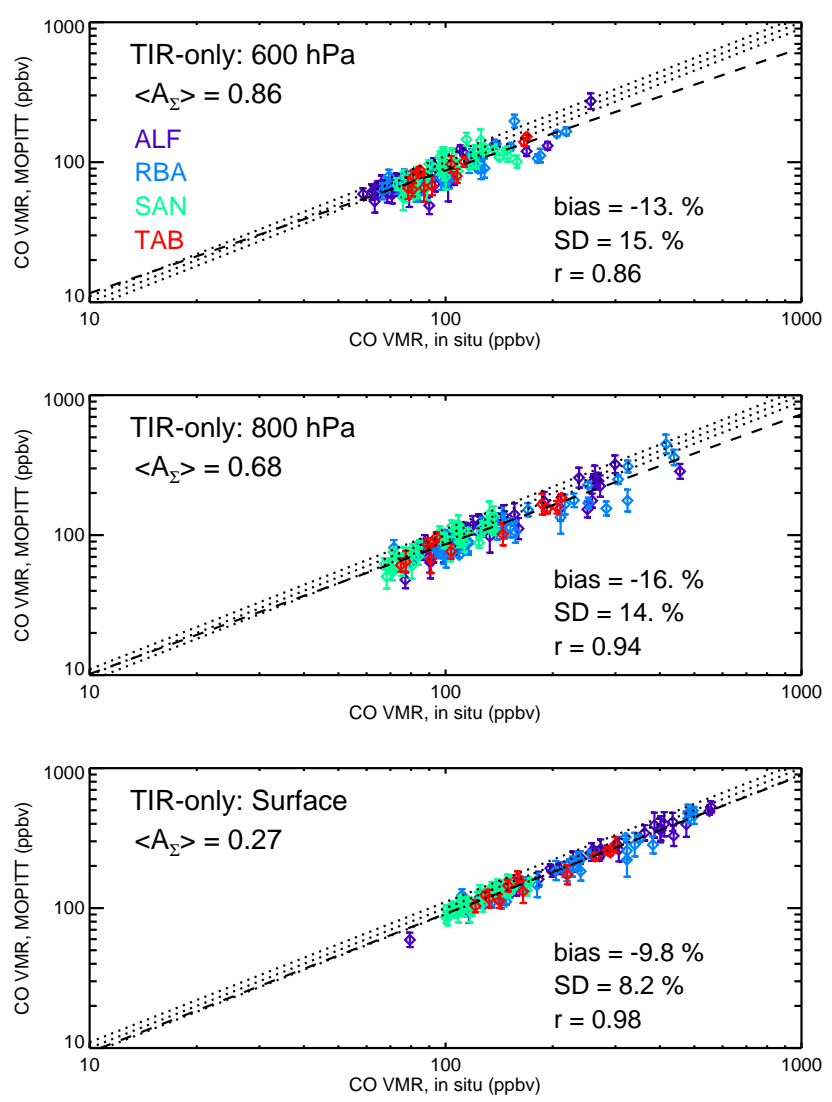

Figure 4. MOPITT Version 6 TIR-only validation results for MOPITT mid- and lower-tropospheric CO retrievals based on aircraft profiles acquired at four Amazonian sites: Alta Floresta (ALF), Rio Branco (RBA), Tabatinga (TAB), and Santarém SAN). Validation statistics are based on $\log (\mathrm{VMR})$, to be consistent with the retrieval state vector. Vertical error bars indicate the variability (standard deviation) of the MOPITT data used to calculate each of the plotted mean values. Each panel shows the least-squares best-fit line (dashed) as well as boundaries around the ideal one-to-one line corresponding to $\pm 10 \%$ errors (indicated by the dotted lines). Summary statistics (bias, standard deviation, and correlation coefficient) are listed on each panel in addition to the mean kernel area $\left(A_{\Sigma}\right)$; this diagnostic provides a useful index for a priori dependence.

For example, for the TIR-only mean averaging kernel for the $800 \mathrm{hPa}$ retrieval level on 17 September 2010, we find that $80 \%$ of the kernel area corresponds to levels within the in situ measured altitude range from the surface to $600 \mathrm{hPa}$. For the $600 \mathrm{hPa}$ retrieval level, $66 \%$ of the kernel area is associated with levels within the measured altitude range. This diagnostic decreases to less than $50 \%$ for higher retrieval levels. Thus, the lack of in situ data above $4.4 \mathrm{~km}$ suggests that validation results will be most meaningful for retrieval levels from the surface to $600 \mathrm{hPa}$.
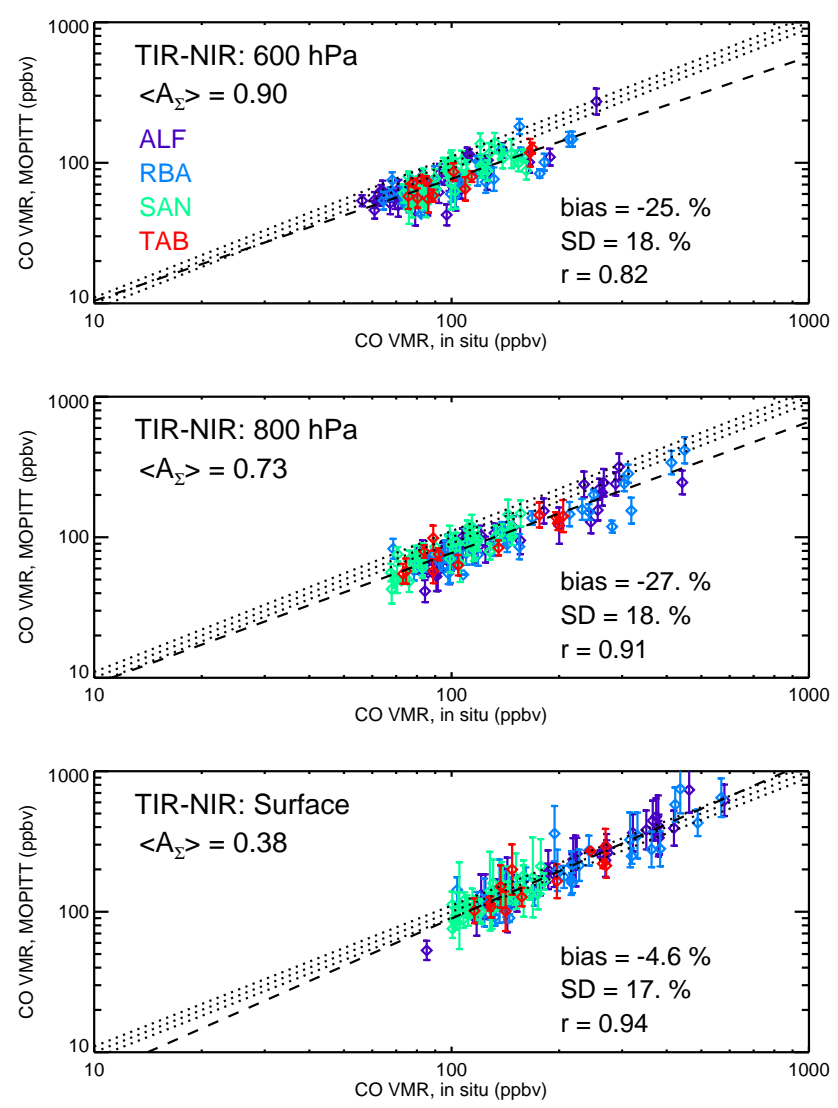

Figure 5. MOPITT Version 6 TIR-NIR validation results for MOPITT mid- and lower-tropospheric CO retrievals based on aircraft profiles acquired at four Amazonian sites. See caption to Fig. 4.

\subsubsection{V6 TIR-only}

Comparisons of MOPITT TIR-only retrieved CO concentrations with simulated retrievals based on in situ data from the four Amazonian sites are presented in Fig. 4. Results for the surface, 800 , and $600 \mathrm{hPa}$ retrieval levels are shown separately. Corresponding comparisons for the MOPITT TIRNIR product are shown in Fig. 5. Each plotted point indicates (1) the mean MOPITT retrieved value for all daytime observations within $200 \mathrm{~km}$ of the site of the in situ data and within 24 of the in situ sampling flight and (2) the mean simulated value calculated after applying Eq. (1) to the in situ profile. (The selected collocation criteria are based on previous experience. The selection of collocation criteria involves a trade-off between the number of analyzed retrievals, which affects the statistical robustness, and errors due to $\mathrm{CO}$ spatial and temporal variability.) Vertical error bars indicate the variability (standard deviation) of the MOPITT data used to calculate each of the plotted mean values. In comparison, uncertainties in the in situ DMF measurements (less than $1 \mathrm{ppb}$ ) are insignificant. Summary statistics (bias, standard deviation, and correlation coefficient) are listed on each panel and in Table 1. 
Mean TIR-only biases at the surface, 800 , and $600 \mathrm{hPa}$ retrieval levels are $-9.8,-16$, and $-13 \%$, respectively, indicating that MOPITT TIR retrievals underestimate surface and lower-tropospheric CO concentrations. For the HIPPO validation results, observed mean TIR-only biases for measurements acquired between $30^{\circ} \mathrm{S}$ and the Equator for the surface, 800 , and $600 \mathrm{hPa}$ retrieval levels were $-1,-2$, and $-2 \%$, respectively. However, the HIPPO validation results were based on relatively few in situ profiles in the same latitude range as the Amazonian profiles (i.e., between $20^{\circ} \mathrm{S}$ and the Equator), possibly because prevailing cloudiness near the ITCZ (Intertropical Convergence Zone) resulted in fewer MOPITT retrievals. Statistically, therefore, the HIPPO results for this latitude range might not be as robust as for other regions. In the latitude range between the Equator and $30^{\circ} \mathrm{N}$, HIPPO mean biases for the surface, 800 , and $600 \mathrm{hPa}$ retrieval levels were $-6,-11$, and $-12 \%$, respectively. Thus, relative to the HIPPO results, observed mean TIR-only retrieval biases for the Amazon appear to be more consistent with the observed biases in the northern tropics than the southern tropics.

As shown in Fig. 4, surface-level in situ CO concentrations (smoothed with the TIR-only averaging kernels) vary from about $100 \mathrm{ppbv}$ to over $500 \mathrm{ppbv}$. In previous MOPITT validation papers (e.g., Deeter et al., 2014), the highest CO concentrations included in the in situ profiles were less than 400 ppbv. Inspection of Fig. 4 indicates that the retrieval biases do not visibly increase at the upper range of $\mathrm{CO}$ concentrations. For example, in the results for the surface and $800 \mathrm{hPa}$, the best-fit line appears to fit the data equally well at low and high $\mathrm{CO}$ concentrations. Thus, for the range of $\mathrm{CO}$ concentrations presented by the Amazonian profiles, the quality of MOPITT TIR-only retrievals appears to be unaffected by high $\mathrm{CO}$ concentrations.

The correlation coefficients for the three retrieval levels decrease with increasing altitude, from 0.98 at the surface to 0.86 at $600 \mathrm{hPa}$. This trend likely reflects both (1) the increasing role of errors associated with the lack of in situ data above $4.4 \mathrm{~km}$ and (2) the stronger a priori weighting for the surface-level retrieval, as indicated by the listed mean kernel area values. The influence of a priori variability on the correlation coefficients is discussed in Sect. 3.2.3.

\subsubsection{V6 TIR-NIR}

As indicated in Fig. 5, mean TIR-NIR biases at the surface, 800 , and $600 \mathrm{hPa}$ retrieval levels are $-4.6,-27$, and $-25 \%$, respectively. Thus, compared to the TIR-only results, the negative bias at the surface is smaller, while the negative biases at 800 and $600 \mathrm{hPa}$ are substantially larger. Like the TIR-only results, the least-squares best-fit lines appear to fit the data equally well at low and high $\mathrm{CO}$ concentrations. Thus, the quality of MOPITT TIR-NIR retrievals also appears to be unaffected by high $\mathrm{CO}$ concentrations.
Table 1. MOPITT validation results based on in situ $\mathrm{CO}$ vertical profiles acquired at four sites in the Amazon Basin from 2010 to 2013. Correlation coefficients shown in parentheses indicate results obtained when a priori influence is excluded, as described in Sect. 3.2.3.

\begin{tabular}{ccccc}
\hline & & Surface & $800 \mathrm{hPa}$ & $600 \mathrm{hPa}$ \\
\hline V6T & Bias (\%) & -9.8 & -16. & -13. \\
& $\mathrm{SD} \mathrm{( \% )}$ & 8.2 & 14. & 15. \\
& $r$ & $0.98(0.87)$ & $0.94(0.82)$ & $0.86(0.75)$ \\
\hline V6J & Bias (\%) & -4.6 & -27. & -25. \\
& $\mathrm{SD} \mathrm{( \% )}$ & 17. & 18. & 18. \\
& $r$ & $0.94(0.72)$ & $0.91(0.77)$ & $0.82(0.69)$ \\
\hline
\end{tabular}

As indicated by both the residual standard deviation values and correlation coefficients listed in Figs. 4 and 5 (and in Table 1), errors for the TIR-NIR product generally appear to be larger than for the TIR-only product. This effect is most evident at the surface, where the standard deviation is $17 \%$ for the TIR-NIR product, compared to $8 \%$ for the TIR-only product. To some extent, larger biases and variable retrieval errors are evident in the TIR-NIR product due to the use of a "gain enhancement factor" to amplify the influence of the NIR radiances in the TIR-NIR product (Deeter et al., 2011). This strategy reduces the retrieval "smoothing error" but also magnifies random retrieval errors due to errors in both the TIR and NIR radiances. However, because of the greater CO sensitivity of the TIR-NIR retrievals (as indicated by the larger mean kernel area $A_{\Sigma}$ ), larger standard deviations would also be expected due to potential CO horizontal gradients within the $200 \mathrm{~km}$ radius used to match MOPITT retrievals with the in situ profiles. Therefore, the larger standard deviation associated with the TIR-NIR product does not by itself necessarily indicate lower retrieval quality.

\subsubsection{Influence of a priori on validation results}

In part, the strong correlations evident in Figs. 4 and 5 are the result of the variability of the a priori, rather than variability of atmospheric $\mathrm{CO}$. As the averaging kernels decrease in magnitude, Eq. (1) indicates that the MOPITT retrieved CO profile (and simulated retrieval based on the in situ profile) should tend toward the a priori profile. To analyze the correlation resulting strictly from actual $\mathrm{CO}$ variability, validation results may be presented in terms of the departure of the retrieved $\log (\mathrm{VMR})$ value from the a priori value, i.e.,

$\Delta x=x_{r t v}-x_{\mathrm{a}}=\mathbf{A}\left(x_{\text {true }}-x_{\mathrm{a}}\right)$.

The validation results illustrated in Figs. 4 and 5 are replotted in terms of $\Delta x$ in Figs. 6 and 7. For the TIR-only results shown in Fig. 6, correlation coefficients at the surface, 800, and $600 \mathrm{hPa}$ are $0.87,0.82$, and 0.75 , respectively. For the TIR-NIR results shown in Fig. 7, the correlation coefficients are $0.72,0.77$, and 0.69 . In both cases, these results demon- 

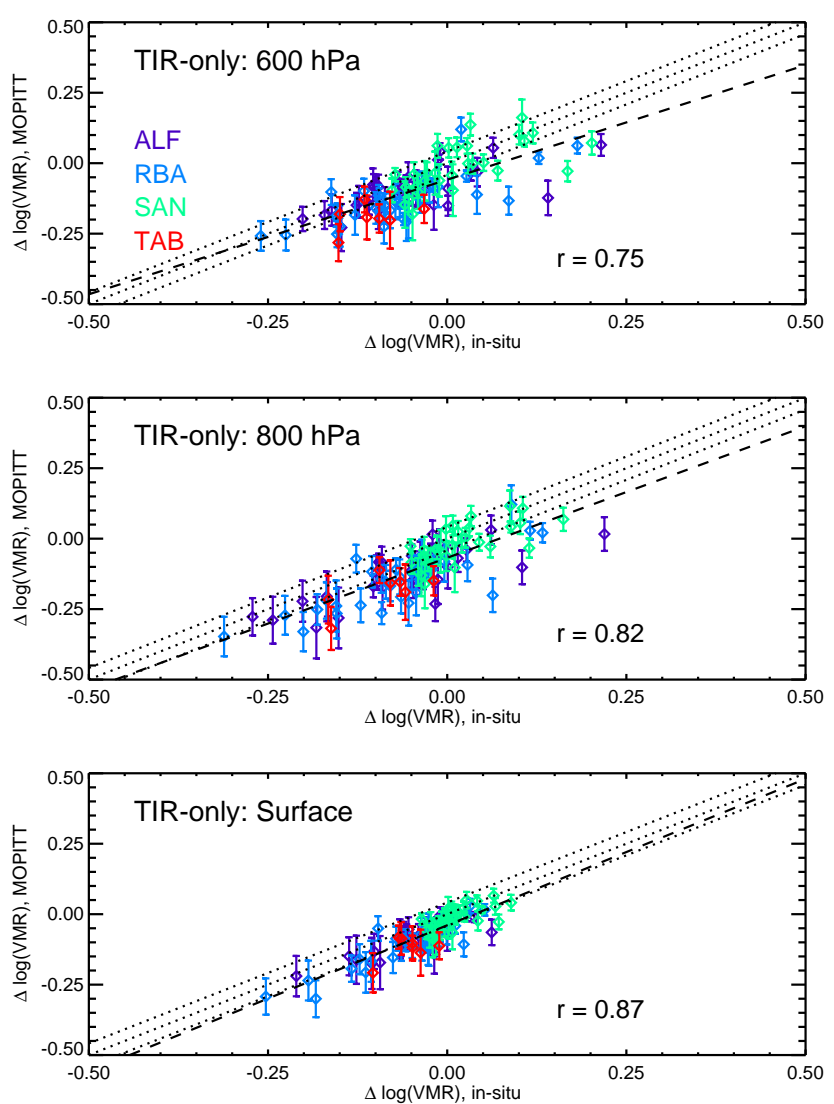

Figure 6. MOPITT Version 6 TIR-only validation results (as presented in Fig. 4), with a priori influence removed from both the MOPITT retrieved values and simulated retrievals based on the in situ data. As discussed in Sect. 3.2.3, plotted values correspond to the difference of retrieved (or simulated) $\log (\mathrm{VMR})$ values and the a priori $\log (\mathrm{VMR})$ value.

strate robust correlations between the retrievals and in situ values, separate from the effects of a priori variability.

\subsubsection{Effects of limited aircraft altitude range}

The set of aircraft in situ profiles used for MOPITT validation include a small subset for which the CO VMR in the extrapolated section of the validation profiles (between 600 and $250 \mathrm{hPa}$ ) was at least $120 \mathrm{ppbv}$. While even higher $\mathrm{CO}$ concentrations have recently been observed in the Amazonian upper troposphere during the dry season (Wendisch et al., 2016), it is plausible that the occurrence of biomass burning plumes at altitudes near $580 \mathrm{hPa}$ (i.e., the altitude of the highest in situ sample) might yield some validation profiles containing overestimated $\mathrm{CO}$ concentrations in the upper troposphere. A simple sensitivity experiment was therefore performed to recalculate the validation statistics after discarding all profiles where the extrapolated mixing ratio was greater than 120 ppbv. Overall, this eliminated about one-sixth of the profiles. For both the TIR-only and TIR-NIR products, the
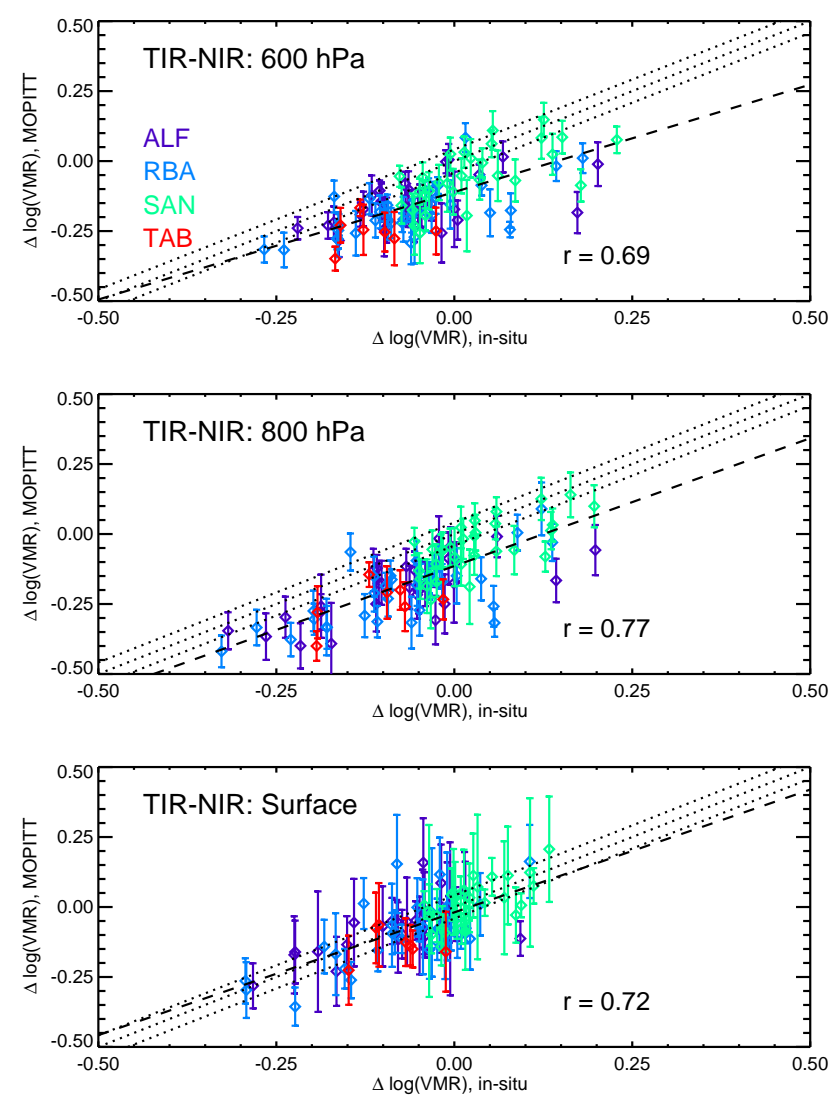

Figure 7. MOPITT Version 6 TIR-NIR validation results (as presented in Fig. 5), with a priori influence removed from both the MOPITT retrieved values and simulated retrievals based on the in situ data. As discussed in Sect. 3.2.3, plotted values correspond to the difference of retrieved (or simulated) $\log (\mathrm{VMR})$ values and the a priori $\log (\mathrm{VMR})$ value.

maximum resulting change in the overall retrieval bias was $3 \%$. Thus, the MOPITT validation results for the surface, 800 , and $600 \mathrm{hPa}$ are not strongly affected by the inclusion of profiles with extrapolated VMR values above 120 ppbv. This finding is consistent with the properties of the MOPITT averaging kernels and provides further evidence that the lack of in situ data above $4.4 \mathrm{~km}$ does not severely affect the validation of the MOPITT retrieval levels in the lower troposphere.

\subsection{Comparisons with AERONET AOD measurements}

The radiative transfer model on which the MOPITT retrieval algorithm is based neglects the potential effects of aerosols (Edwards et al., 1999). While aerosols often produce significant radiative effects in the ultraviolet and visible spectral regions, aerosol optical depth (AOD) diminishes rapidly with increasing wavelength (Eck et al., 1999). (MOPITT's NIR channels operate in the $2.3 \mu \mathrm{m}$ band, while MOPITT's TIR channels operate in the $4.7 \mu \mathrm{m}$ band.) Thus, in most atmospheric conditions, aerosols probably have a negligible effect 
on MOPITT retrieval error. However, MOPITT validation results have never previously been reported for regions strongly affected by biomass burning emissions, where AODs of one or greater are often observed (Eck et al., 1999).

For MOPITT CO retrievals, dense smoke aerosols produced by biomass burning could conceivably cause retrieval errors through at least two mechanisms. For MOPITT's NIR channels, scattering from aerosol particles could potentially alter the effective optical path length through the atmosphere. This effect is explicitly represented in retrieval algorithms for carbon dioxide and methane using satellite observations in spectral bands near 1.6 and $2.0 \mu \mathrm{m}$ (Butz et al., 2011; Yoshida et al., 2013). Alternatively, extreme aerosol concentrations might locally affect meteorological conditions, either by reducing insolation at the surface or through atmospheric heating caused by absorbing aerosols such as black carbon (Ramanathan and Carmichael, 2008). This effect could indirectly result in retrieval error for both the TIR-only and TIR-NIR retrievals if it caused a significant error in the assumed atmospheric temperature profile. Temperature and water vapor profiles used in MOPITT V6 retrieval processing are extracted from the MERRA (Modern-Era Retrospective Analysis for Research and Applications) reanalysis product (http://gmao.gsfc.nasa.gov/merra/).

Two of the four Amazonian sites for which aircraft $\mathrm{CO}$ profiles were exploited for MOPITT validation in Sect. 3.2 also host AERONET stations (Holben et al., 2001). This coincidence permits the analysis of the dependence of MOPITT retrieval biases on AOD. Possible MOPITT aerosoldependent retrieval biases were studied by comparing MOPITT retrieval biases at $800 \mathrm{hPa}$ from Sect. 3.2 with groundbased AOD measurements at $500 \mathrm{~nm}$ from the Alta Floresta and Rio Branco AERONET sites. The $800 \mathrm{hPa}$ retrieval level was selected for this comparison because (1) the averaging kernel area for this level typically indicates a weak dependence on the a priori for both the TIR-only and TIR-NIR products and (2) calculated retrieval biases at this level are not strongly affected by the lack of in situ data for the upper troposphere (as described above). AOD values at $500 \mathrm{~nm}$ were extracted from AERONET daily-mean data files for the same dates on which the aircraft in situ data were acquired.

The dependence of MOPITT retrieval bias at $800 \mathrm{hPa}$ on AOD for both the TIR-only and TIR-NIR products is presented in Fig. 8. Each plotted point indicates the mean MOPITT retrieval bias and daily-mean AOD for a single daytime MOPITT overpass of one of the two AERONET sites. While there are relatively few data points indicating high AOD values, the plotted data do not appear to demonstrate a clear AOD dependence for the retrieval bias for either type of MOPITT product. To analyze the relationship further, mean and standard deviation retrieval bias values were calculated separately for data subsets where AOD $<0.5$ (a total of 28 overpasses) and $\mathrm{AOD}>=0.5$ (nine overpasses). Presumably, if aerosols did produce a systematic retrieval bias, it would be revealed by comparing the means and standard deviations for
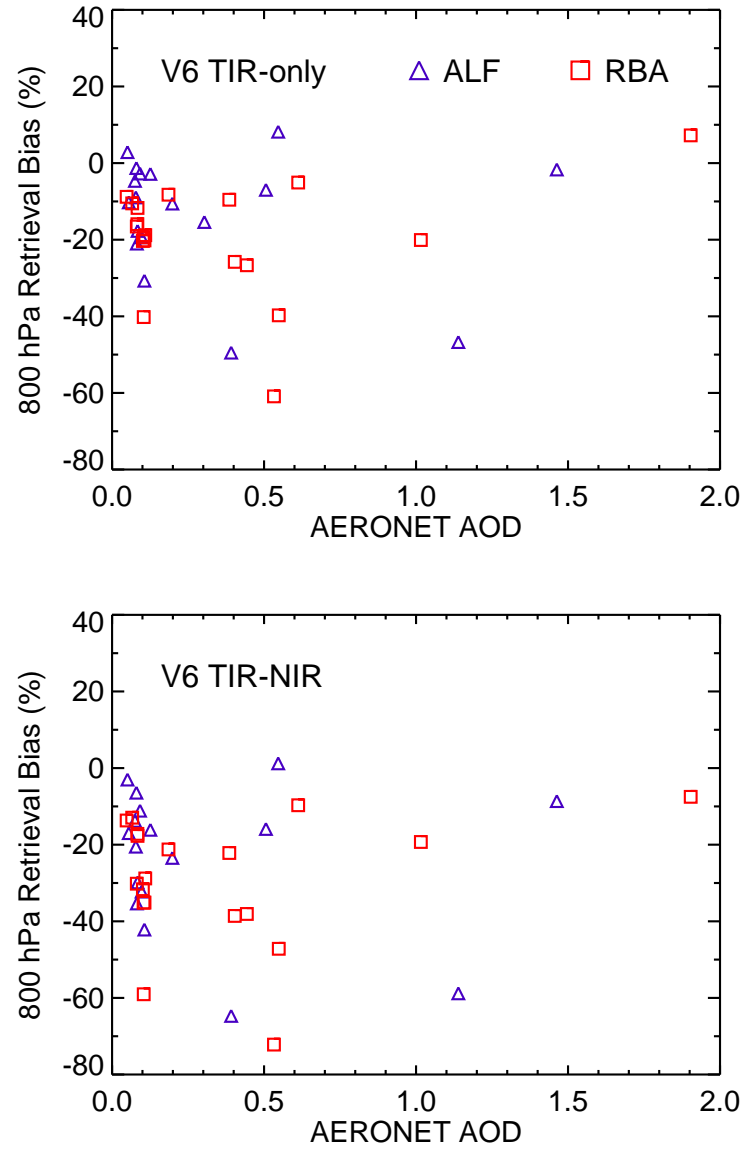

Figure 8. Comparison of observed MOPITT TIR-only and TIRNIR retrieval biases at $800 \mathrm{hPa}$ at two Amazonian sites with groundbased measurements of aerosol optical depth at $500 \mathrm{~nm}$ from the AERONET network. Each plotted point indicates the mean MOPITT retrieval bias and daily-mean AOD for a single daytime MOPITT overpass of one of the two AERONET sites. While there are relatively few data points at high AOD values, the plotted data do not indicate a clear AOD dependence for the retrieval bias for either type of MOPITT product.

these two subsets. For the TIR-only data, the overall bias for the low-AOD subset was $-15.9 \pm 11.5 \%$ and for the highAOD subset was $-18.4 \pm 25.0 \%$. For the TIR-NIR data, the overall bias for the low-AOD subset was $-28.7 \pm 18.2 \%$ and for the high-AOD subset was $-26.4 \pm 26.1 \%$. Thus, a systematic retrieval bias related to aerosols is not indicated in either the MOPITT TIR-only or TIR-NIR product. The greater standard deviations observed for the AOD $>=0.5$ subsets might be explained by stronger $\mathrm{CO}$ geographical and temporal variability during the Amazonian dry season; however this is only a hypothesis. 


\section{Observed CO variability over the Amazon Basin}

Significant interannual variability in $\mathrm{CO}$ concentrations over the Amazon Basin primarily results from two sources: deforestation and understory fires. Annual deforestation rates in the "Legal Amazon" region estimated by Brazil's PRODES (Program to Calculate Deforestation in the Amazon) satellite-based monitoring system (www.obt.inpe.br/ prodes/index.php) plummeted from $27772 \mathrm{~km}^{2} \mathrm{yr}^{-1}$ in 2004 to $4571 \mathrm{~km}^{2} \mathrm{yr}^{-1}$ in 2012 . Suggested causes of falling deforestation rates in Brazil include (1) the expansion of protected areas in Brazil; (2) increased monitoring and law enforcement; and (3) market forces, including declining soy prices and economic disincentives for landholders implicated in deforestation (Nepstad et al., 2009; Macedo et al., 2012). While much of the biomass burning activity in Amazonia relates directly to land use practices, human-initiated fires often escape from deforested areas into neighboring standing forests (Cochrane, 2003; Morton et al., 2013). These fires typically spread slowly in the forest understory, mainly consuming leaf litter, yet cause substantial long-term damage to the tropical forest ecosystem (Peres, 1999; Cochrane, 1999). Regionally, areas burned in understory fires may be comparable to or larger than clear-cut areas (Morton et al., 2013; Alencar et al., 2006; Aragão et al., 2007). Areas burned in understory fires are particularly extensive during droughts, indicating some degree of climate influence (Alencar et al., 2006).

The MOPITT data record enables the analysis of evolving $\mathrm{CO}$ concentrations over the Amazon Basin. In the following, we examine the $\mathrm{CO}$ record based on the MOPITT V6 TIR-NIR Level 3 monthly-mean product. MOPITT Level 3 products are gridded at $1^{\circ}$ resolution (latitude and longitude) and are gridded separately for daytime and nighttime overpasses; the following analysis only exploits daytime Level 3 data. For analyzing $\mathrm{CO}$ variability over a relatively large region and over multiple years, analyzing Level 3 monthlymean products is much more efficient than for Level 2 data. MOPITT records of basin-averaged $\mathrm{CO}$ total column are analyzed in addition to retrieved $\mathrm{CO}$ concentrations at the surface and at $400 \mathrm{hPa}$. While no new validation results are presented in this manuscript for $400 \mathrm{hPa}$, TIR-NIR averaging kernels for this level (shown in Figs. 2 and 3) demonstrate its usefulness as a retrieval of upper-tropospheric $\mathrm{CO}$ concentrations with very weak sensitivity to $\mathrm{CO}$ in the lower troposphere.

In the following analysis, no attempt was made to correct the MOPITT data for retrieval bias or bias drift. For interpreting the mean $\mathrm{CO}$ annual cycle, validation results presented above imply that TIR-NIR long-term monthly means shown in Sect. 4.1 likely underestimate both true CO concentrations at the surface and $\mathrm{CO}$ total column values. For the upper troposphere, the retrieval bias over the Amazon Basin is not well characterized, although HIPPO TIR-NIR validation results for the tropics indicate biases at $400 \mathrm{hPa}$ between -10 and $0 \%$. Temporally fixed retrieval biases would
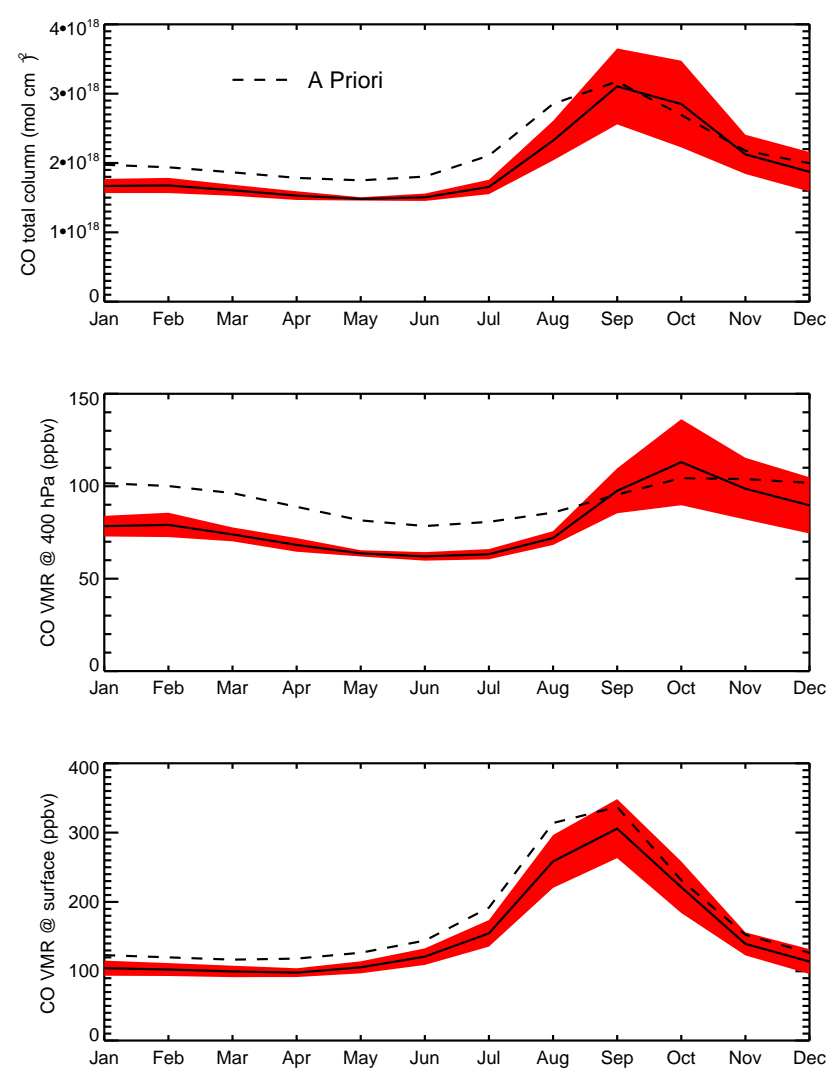

Figure 9. MOPITT TIR-NIR long-term monthly means of retrieved $\mathrm{CO}$ total column and $\mathrm{CO}$ concentrations for the Amazon Basin, based on observations from 2002 to 2015 . Shaded red area indicates variability (standard deviation) of monthly means. Monthly-mean a priori values are also indicated for comparison.

not necessarily affect the interpretation of interannual variability presented in Sect. 4.2, although the bias long-term trend (or "bias drift") should be considered in that case. Previous TIR-NIR validation results based on $\mathrm{CO}$ vertical profiles measured over North America (Deeter et al., 2014) indicated a bias drift for the $400 \mathrm{hPa}$ level of $1.08 \% \mathrm{yr}^{-1}$ and for the surface of $-0.48 \% \mathrm{yr}^{-1}$ but only a very weak bias drift for CO total column $\left(0.003 \times 10^{18} \mathrm{~mol} \mathrm{~cm}^{-2} \mathrm{yr}^{-1}\right)$. However, the geographical variability of bias drift has not yet been investigated.

\subsection{The annual cycle: long-term monthly means}

Long-term monthly means were calculated by separately averaging Level 3 (gridded) MOPITT CO data for each month over the period from 2002 to 2015 and are presented in Fig. 9. (MOPITT data from 2000, 2001, and 2009 were excluded from these long-term averages because of instrumental anomalies that resulted in incomplete years of observations.) Geographically, $\mathrm{CO}$ data were averaged for all grid cells within the digitized boundaries of the Amazon Basin as defined for the "Large-Scale Biosphere-Atmosphere Exper- 

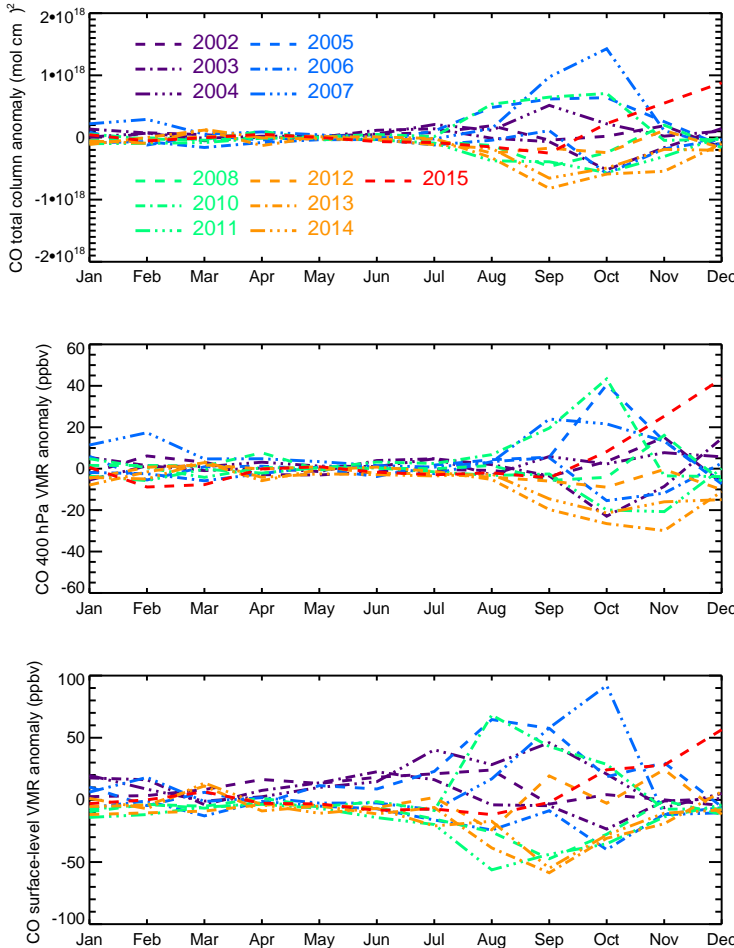

Figure 10. Monthly-mean anomalies of MOPITT TIR-NIR CO products for each of the years used to generate the long-term monthly means shown in Fig. 9.

iment in Amazonia" field campaign (https://daac.ornl.gov/ LBA/lba.shtml). Grid cells with no data (due to persistent cloudiness) were excluded from the long-term monthly-mean basin averages. Thus, during the Amazonian wet season from January to May, the presented monthly-mean basin averages may reflect $\mathrm{CO}$ concentrations only over some fraction of the entire Amazon Basin. Separate panels in Fig. 9 indicate MOPITT long-term monthly means for $\mathrm{CO}$ total column, $400 \mathrm{hPa} \mathrm{CO}$, and surface-level CO concentrations. The interannual variability (standard deviation) of the monthly means used to calculate the long-term monthly means is indicated by the red shaded area. Mean a priori values were also calculated from the Level 3 data files and are shown as dashed lines. V6 a priori $\mathrm{CO}$ concentrations are derived from a model-based climatology for the years 2000-2009, using the CAM-chem chemical transport model and GFED2 emissions.

In all three panels, long-term mean $\mathrm{CO}$ concentrations appear generally stable from January to June. As the dry season develops, mean $\mathrm{CO}$ concentrations then increase along with the $\mathrm{CO}$ interannual variability (as indicated by the width of the red shaded area). At the surface, mean $\mathrm{CO}$ concentrations begin to increase in June, followed by a larger increase in July. Mean surface-level CO concentrations peak in September, for which the long-term monthly mean is approximately 3 times the mean for the wet-season months. Mean CO con- centrations at the surface follow the annual cycle indicated by the a priori but are generally smaller by $10-20 \%$. (This difference would be somewhat smaller if we accounted for the observed retrieval bias of $-4.6 \%$ found in Sect. 3.2.) At $400 \mathrm{hPa}$, increased $\mathrm{CO}$ concentrations are generally not observed until August, and mean concentrations peak in October. The delayed peak in CO concentrations at $400 \mathrm{hPa}$ (compared to the surface) likely reflects the characteristic time required for $\mathrm{CO}$ produced at the surface to ascend into the upper troposphere. Observed mean $\mathrm{CO}$ concentrations at $400 \mathrm{hPa}$ exhibit a stronger annual cycle compared to the a priori and are about $20 \%$ smaller during the wet-season months.

\subsection{Interannual variability}

$\mathrm{CO}$ monthly anomalies for the Amazon Basin were calculated by subtracting the long-term monthly means (shown in Fig. 9) from the monthly means for each individual year of MOPITT observations. The resulting anomaly time series for CO total column, CO VMR at $400 \mathrm{hPa}$, and surface-level VMR are shown in Fig. 10. Monthly-mean anomalies during the period from January to June exhibit little interannual variability for $\mathrm{CO}$ total column and at $400 \mathrm{hPa}$, but exhibit significant interannual variability for surface-level CO. However, for this period, the apparent interannual variability at the surface is qualitatively consistent with the expected result of bias drift as described above; i.e., monthly-mean anomalies exhibit an overall decreasing trend. Thus, the apparent interannual variability of surface-level $\mathrm{CO}$ for the months between January and June might not be significant.

The 3 years indicating the largest positive anomalies in Fig. 10 are 2005, 2007, and 2010. These years correspond to years when exceptionally large areas burned in Amazonian understory fires (Morton et al., 2013). Extensive droughts were recorded in the Amazon Basin in both 2005 and 2010 (Lewis et al., 2011). Factors which contributed to the relatively large CO emissions in 2007 were recently analyzed in Bloom et al. (2015). The apparent association of large CO anomalies with understory fires illustrates the importance of climate-driven fires to the Amazonian carbon budget. Efforts to reduce deforestation in the Amazon Basin may not affect future emissions from understory fires (Morton et al., 2013).

Significant negative dry-season monthly anomalies are apparent for 2011, 2013, and 2014. Excluding the years 2005, 2007 , and 2010, the history of monthly anomalies presented in Fig. 10 generally indicates an overall long-term trend toward decreasing $\mathrm{CO}$ emissions from the Amazon Basin since 2002. This trend might be the result of falling deforestation rates (Nepstad et al., 2009) or may be related to climate. However, this trend does not seem to hold for the most recent year of the analysis. While monthly-mean anomalies for 2015 are relatively weak in the early dry-season months, exceptionally strong positive anomalies for 2015 are evident in November and December. 


\section{Conclusions}

Biomass burning emissions inventories such as GFED and FINN are widely used in modeling simulations, despite their large uncertainties. Satellite observations of $\mathrm{CO}$ might be useful for refining such inventories. This work demonstrates the utility of MOPITT products for analyzing $\mathrm{CO}$ emissions from the Amazon Basin. Comparisons of retrieval averaging kernels and values of degrees of freedom for signal for MOPITT TIR-only and TIR-NIR products indicate enhanced sensitivity to CO in the lower troposphere for the TIR-NIR product, particularly during the Amazonian dry season. Validation results based on routine sampling flights at four sites in the Amazon Basin exhibit a negative bias in MOPITT V6 retrievals of $\mathrm{CO}$ in the lower troposphere but do not indicate degraded performance in high-CO scenes. Likewise, comparisons with ground-based AOD measurements do not reveal retrieval biases associated with dense smoke from biomass burning. Over the MOPITT mission, observed longterm monthly-mean surface-level CO concentrations averaged over the Amazon Basin are generally similar to the $\mathrm{CO}$ climatology used as the retrieval a priori, whereas observed long-term mean $\mathrm{CO}$ concentrations at $400 \mathrm{hPa}$ exhibit a much stronger annual cycle. A brief analysis of the history of monthly-mean anomalies for the Amazon Basin indicates that the largest $\mathrm{CO}$ emissions occurred in years when drought-driven understory fires burned exceptionally large areas.

\section{Data availability}

MOPITT Version 6 Level 2 and Level 3 data used for this research are available at the NASA Atmospheric Sciences Data Center (ASDC) datapool at https://eosweb.larc.nasa. gov/datapool. MODIS Collection 5 fire count data were obtained from http://modis-fire.umd.edu.

Acknowledgements. The authors thank Brent Holben and the AERONET team for making the AERONET data publicly available. The NCAR MOPITT project is supported by the National Aeronautics and Space Administration (NASA) Earth Observing System (EOS) program. The National Center for Atmospheric Research (NCAR) is sponsored by the National Science Foundation. We thank Louis Giglio for making the MODIS fire count data available.

Edited by: T. Röckmann

Reviewed by: two anonymous referees

\section{References}

Alencar, A., D. Nepstad, and M. Diaz: Forest Understory Fire in the Brazilian Amazon in ENSO and Non-ENSO Years: Area
Burned and Committed Carbon Emissions, Earth Interact., 10, 1-17, doi:10.1175/EI150.1, 2006.

Andreae, M. O. and P. Merlet: Emission of trace gases and aerosols from biomass burning, Global Biogeochem. Cy., 15, 955-966, doi:10.1029/2000GB001382, 2001.

Andreae, M. O., Artaxo, P., Beck, V., Bela, M., Freitas, S., Gerbig, C., Longo, K., Munger, J. W., Wiedemann, K. T., and Wofsy, S. C.: Carbon monoxide and related trace gases and aerosols over the Amazon Basin during the wet and dry seasons, Atmos. Chem. Phys., 12, 6041-6065, doi:10.5194/acp-12-6041-2012, 2012.

Aragão, L. E. O. C. and Y. E. Shimabukuro: The incidence of fire in Amazonian forests with implications for REDD, Science, 328, 1275-1278, doi:10.1126/science.1186925, 2010.

Aragão, L. E. O. C., Malhi, Y., Roman-Cuesta, R. M., Saatchi, S., Anderson, L. O., and Shimabukuro, Y. E.: Spatial patterns and fire response of recent Amazonian drought, Geophys. Res. Lett., 34, L07701, doi:10.1029/2006GL028946, 2007.

Arellano, A. F., Jr., Kasibhatla, P. S., Giglio, L., van der Werf, G. R., Randerson, J. T., and Collatz, G. J.: Time-dependent inversion estimates of global biomass-burning CO emissions using Measurement of Pollution in the Troposphere (MOPITT) measurements, J. Geophys. Res., 111, D09303, doi:10.1029/2005JD006613, 2006.

Bloom, A. A., Worden, J., Jiang, Z., Worden, H., Kurosu, T., Frankenberg, C., and Schimel, D.: Remote-sensing constraints on South America fire traits by Bayesian fusion of atmospheric and surface data, Geophys. Res. Lett., 42, 1268-1274, doi:10.1002/2014GL062584, 2015.

Butz, A., Guerlet, S., Hasekamp, O., Schepers, D., Galli, A., Aben, I., Frankenberg, C., Hartmann, J.-M., Tran, H., Kuze, A., Keppel-Aleks, G., Toon, G., Wunch, D., Wennberg, P., Deutscher, N., Griffith, D., Macatangay, R., Messerschmidt, J., Notholt, J., and Warneke, T.: Toward accurate $\mathrm{CO}_{2}$ and $\mathrm{CH}_{4}$ observations from GOSAT, Geophys. Res. Lett., 38, L14812, doi:10.1029/2011GL047888, 2011.

Chevallier, F., R. J. Engelen, and P. Peylin: The contribution of AIRS data to the estimation of $\mathrm{CO} 2$ sources and sinks, Geophys. Res. Lett., 32, L23801, doi:10.1029/2005GL024229, 2005.

Cochrane, M.: Fire science for rainforests, Nature, 421, 913-919, doi:10.1038/nature01437, 2003.

Cochrane, M. A.: Positive Feedbacks in the Fire Dynamic of Closed Canopy Tropical Forests, Science, 284, 1832-1834, 1999.

Deeter, M. N., Emmons, L. K., Francis, G. L., Edwards, D. P., Gille, J. C., Warner, J. X., Khattatov, B., Ziskin, D., Lamarque, J.-F., Ho, S.-P., Yudin, Attié, J.-L., Packman, D., Chen, J., Mao, D., and Drummond, J. R.: Operational carbon monoxide retrieval algorithm and selected results for the MOPITT instrument, J. Geophys. Res., 108, 4399, doi:10.1029/2002JD003186, 2003.

Deeter, M. N., Edwards, D. P., Gille, J. C., and Drummond, J. R.: Sensitivity of MOPITT observations to carbon monoxide in the lower troposphere, J. Geophys. Res., 112, D24306, doi:10.1029/2007JD008929, 2007.

Deeter, M. N., Edwards, D. P., Gille, J. C., Emmons, L. K., Francis, G., Ho, S.-P., Mao, D., Masters, D., Worden, H., Drummond, J. R., and Novelli, P. C.: The MOPITT version 4 CO product: Algorithm enhancements, validation, and long-term stability, J. Geophys. Res., 115, D07306, doi:10.1029/2009JD013005, 2010.

Deeter, M. N., Worden, H. M., Gille, J. C., Edwards, D. P., Mao, D., and Drummond, J. R.: MOPITT multispectral CO retrievals: 
Origins and effects of geophysical radiance errors, J. Geophys. Res., 116, D15303, doi:10.1029/2011JD015703, 2011.

Deeter, M. N., Martínez-Alonso, S., Edwards, D. P., Emmons, L. K., Gille, J. C., Worden, H. M., Pittman, J. V., Daube, B. C., and Wofsy, S. C.: Validation of MOPITT Version 5 thermalinfrared, near-infrared, and multispectral carbon monoxide profile retrievals for 2000-2011, J. Geophys. Res., 118, 6710-6725, doi:10.1002/jgrd.50272, 2013.

Deeter, M. N., Martínez-Alonso, S., Edwards, D. P., Emmons, L. K., Gille, J. C., Worden, H. M., Sweeney, C., Pittman, J. V., Daube, B. C., and Wofsy, S. C.: The MOPITT Version 6 product: algorithm enhancements and validation, Atmos. Meas. Tech., 7, 3623-3632, doi:10.5194/amt-7-3623-2014, 2014.

Deeter, M. N., Edwards, D. P., Gille, J. C., and Worden, H. M.: Information content of MOPITT CO profile retrievals: Temporal and geographical variability. J. Geophys. Res., 120, 1272312738, doi:10.1002/2015JD024024, 2015.

Drummond, J., Zou, J., Nichitiu, F., Kar, J., Deschambaut, R., and Hackett, J.: A review of 9-year performance and operation of the MOPITT instrument, Adv. Space Res., 45, 760-774, doi:10.1016/j.asr.2009.11.019, 2010.

Eck, T. F., Holben, B. N., Reid, J. S., Dubovik, O., Smirnov, A., O’Neill, N. T., Slutsker, I., and Kinne, S.: Wavelength dependence of the optical depth of biomass burning, urban, and desert dust aerosols, J. Geophys. Res., 104, 31333-31349, 2006.

Edwards, D. P., C. M. Halvorson, and J. C. Gille: Radiative transfer modeling for the EOS Terra satellite Measurements of Pollution in the Troposphere (MOPITT) instrument, J. Geophys. Res., 104, $16755-16775,1999$.

Edwards, D. P., Emmons, L. K., Gille, J. C., Chu, A., Attié, J.-L., Giglio, L., Wood, S. W., Haywood, J., Deeter, M. N., Massie, S. T., Ziskin, D. C., and Drummond, J. R.: Satellite-observed pollution from Southern Hemisphere biomass burning, J. Geophys. Res., 111, D14312, doi:10.1029/2005JD006655, 2006.

Emmons, L. K., Edwards, D. P., Deeter, M. N., Gille, J. C., Campos, T., Nédélec, P., Novelli, P., and Sachse, G.: Measurements of Pollution In The Troposphere (MOPITT) validation through 2006, Atmos. Chem. Phys., 9, 1795-1803, doi:10.5194/acp-91795-2009, 2009.

Fortems-Cheiney, A., Chevallier, F., Pison, I., Bousquet, P., Szopa, S., Deeter, M. N., and Clerbaux, C.: Ten years of $\mathrm{CO}$ emissions as seen from Measurements of Pollution in the Troposphere MOPITT, J. Geophys. Res., 116, D05304, doi:10.1029/2010JD014416, 2011.

Gatti, L. V., Gloor, M., Miller, J. B., Doughty, C. E., Malhi, Y., Domingues, L. G., Basso, L. S., Martinewski, A., Correia, C. S. C., Borges, V. F., Freitas, S., Braz, R., Anderson, L. O., Rocha, H., Grace, J., Phillips, O. L., and Lloyd, J.: Drought sensitivity of Amazonian carbon balance revealed by atmospheric measurements, Nature, 506, 76-80, doi:10.1038/nature12957, 2014.

Giglio, L., J. T. Randerson, and G. R. van der Werf: Analysis of daily, monthly, and annual burned area using the fourthgeneration global fire emissions database (GFED4), J. Geophys. Res.Biogeo., 118, 317-328, doi:10.1002/jgrg.20042, 2013.

Gullison, R. E., Frumhoff, P. C., Canadell, J. G., Field, C. B., Nepstad, D. C., Hayhoe, K., Avissar, R., Curran, L. M., Friedlingstein, P., Jones, C. D., and Nobre, C.: Tropical forests and climate policy, Science, 316, 985-986, doi:10.1126/science.1136163, 2007.
Holben, B. N., Tanré, D., Smirnov, A., Eck, T. F., Slutsker, I., Abuhassan, N., Newcomb, W. W., Schafer, J. S., Chatenet, B., Lavenu, F., Kaufman, Y. J., Vande Castle, J., Setzer, A., Markham, B., Clark, D., Frouin, R., Halthore, R., Karneli, A., O’Neill, N. T., Pietras, C., Pinker, R. T., Voss, K., and Zibordi, G.: An emerging ground-based aerosol climatology: Aerosol optical depth from AERONET, J. Geophys. Res., 106, 1206712097, doi:10.1029/2001JD900014, 2001.

Hooghiemstra, P. B., Krol, M. C., vanLeeuwen, T. T., van derWerf, G. R., Novelli, P. C., Deeter, M. N.,Aben, I., and Röckmann, T.: Interannual variability of carbon monoxide emission estimates over South America from 2006 to 2010, J. Geophys. Res., 117, D15308, doi:10.1029/2012JD017758, 2012.

Kopacz, M., Jacob, D. J., Fisher, J. A., Logan, J. A., Zhang, L., Megretskaia, I. A., Yantosca, R. M., Singh, K., Henze, D. K., Burrows, J. P., Buchwitz, M., Khlystova, I., McMillan, W. W., Gille, J. C., Edwards, D. P., Eldering, A., Thouret, V., and Nedelec, P.: Global estimates of $\mathrm{CO}$ sources with high resolution by adjoint inversion of multiple satellite datasets (MOPITT, AIRS, SCIAMACHY, TES), Atmos. Chem. Phys., 10, 855-876, doi:10.5194/acp-10-855-2010, 2010.

Lamarque, J.-F., Emmons, L. K., Hess, P. G., Kinnison, D. E., Tilmes, S., Vitt, F., Heald, C. L., Holland, E. A., Lauritzen, P. H., Neu, J., Orlando, J. J., Rasch, P. J., and Tyndall, G. K.: CAM-chem: description and evaluation of interactive atmospheric chemistry in the Community Earth System Model, Geosci. Model Dev., 5, 369-411, doi:10.5194/gmd-5-369-2012, 2012.

Lewis, S. L., Brando, P. M., Phillips, O. L., van der Heijden, G. M. F., and Nepstad, D.: The 2010 Amazon Drought, Science, 331 p. 554,2011

Macedo, M. N., DeFries, R. S., Morton, D. C., Stickler, C. M., Galford, G. L., and Shimabukuro, Y. E.: Decoupling of deforestation and soy production in the southern Amazon during the late 2000s, P. Natl. Acad. Sci. USA, 109, 1341-1346, doi:10.1073/pnas.1111374109, 2012.

Malhi, Y., Roberts, J. T., Betts, R. A., Killeen, T. J., Li, W., and Nobre, C. A. : Climate Change, Deforestation, and the Fate of the Amazon, Science, 319, 169-172, doi:10.1126/science.1146961, 2008.

Miles, L. and V. Kapos: Reducing Greenhouse Gas Emissions from Deforestation and Forest Degradation: Global Land-Use Implications, Science, 320, 1454-1455, 2008.

MODIS: MODIS Collection 5 fire count data, available at: http:// modis-fire.umd.edu, last access: August 2016.

Morton, D. C., Le Page, Y., DeFries, R., Collatz, G. J., and Hurtt, G. C.: Understorey fire frequency and the fate of burned forests in southern Amazonia, Philos. T. Roy. Soc. B, 368, doi:10.1098/rstb.2012.0163, 2013.

NASA Atmospheric Sciences Data Center: MOPITT Version 6 Level 2 and Level 3 data, available at: https://eosweb.larc.nasa. gov/datapool, last access: August 2016.

Nepstad, D., Soares-Filho, B. S., Merry, F., Lima, A., Moutinho, P., Carter, J., Bowman, M., Cattaneo, A., Rodrigues, H., Schwartzman, S., McGrath, D. G., Stickler, C. M., Lubowski, R., PirisCabezas, P., Rivero, S., Alencar, A., Almeida, O., and Stella, O.: The End of Deforestation in the Brazilian Amazon, Science, 326, 350-351, 2009. 
Pan, L., Gille, J. C., Edwards, D. P., Bailey, P. L., and Rodgers. C. D.: Retrieval of carbon monoxide for the MOPITT instrument, J. Geophys. Res., 103, 32277-32290, 1998.

Peres, C. A.: Ground fires as agents of mortality in a Central Amazonian forest, J. Trop. Ecol., 15, 535-541, 1999.

Ramanathan, V. and G. Carmichael: Global and regional climate changes due to black carbon, Nat. Geosci., 1, 221-227, doi:10.1038/ngeo156, 2008.

Rodgers, C. D.: Inverse Methods for Atmospheric Sounding, Theory and Practice, World Scientific, Singapore, 2000.

van der Werf, G. R., Randerson, J. T., Giglio, L., Collatz, G. J., Kasibhatla, P. S., and Arellano Jr., A. F.: Interannual variability in global biomass burning emissions from 1997 to 2004, Atmos. Chem. Phys., 6, 3423-3441, doi:10.5194/acp-6-3423-2006, 2006.

Wendisch, C., Pöschl, U., Andreae, M. O., Machado, L. A. T., Albrecht, R., Schlager, H., Rosenfeld, D., Martin, S. T., Abdelmonem, A., Afchine, A., Araùjo, A., Artaxo, P., Aufmhoff, H., Barbosa, H. M. J., Borrmann, S., Braga, R., Buchholz, B., Cecchini, M. A., Costa, A., Curtius, J., Dollner, M., Dorf, M., Dreiling, V., Ebert, V., Ehrlich, A., Ewald, F., Fisch, G., Fix, A., Frank, F., Fütterer, D., Heckl, C., Heidelberg, F., Hüneke, T., Jäkel, E., Järvinen, E., Jurkat, T., Kanter, S., Kästner, U., Kenntner, M., Kesselmeier, J., Klimach, T., Knecht, M., Kohl, R., Kölling, T., Krämer, M., Krüger, M., Krisna, T. C., Lavric, J. V., Longo, K., Mahnke, C., Manzi, A. O., Mayer, B., Mertes, S., Minikin, A., Molleker, S., Münch, S., Nillius, B., Pfeilsticker, K., Pöhlker, C., Roiger, A., Rose, D., Rosenow, D., Sauer, D., Schnaiter, M., Schneider, J.,Schulz, C., de Souza, R. A. F., Spanu, A., Stock, P., Vila, D., Voigt, C., Walser, A., Walter, D., Weigel, R., Weinzierl, B., Werner, F., Yamasoe, M. A., Ziereis, H., Zinner, T., and Zöger, M.: The ACRIDICON-CHUVA campaign: Studying tropical deep convective clouds and precipitation over Amazonia using the new German research aircraft HALO, B. Am. Meteorol. Soc., doi:10.1175/BAMS-D-14-00255.1, 2016.
Wiedinmyer, C., Akagi, S. K., Yokelson, R. J., Emmons, L. K., AlSaadi, J. A., Orlando, J. J., and Soja, A. J.: The Fire INventory from NCAR (FINN): a high resolution global model to estimate the emissions from open burning, Geosci. Model Dev., 4, 625641, doi:10.5194/gmd-4-625-2011, 2011.

Worden, H. M., Deeter, M. N., Edwards, D. P., Gille, J. C., Drummond, J. R., and Nédélec, P.: Observations of near-surface carbon monoxide from space using MOPITT multispectral retrievals, J. Geophys. Res., 115, D18314, doi:10.1029/2010JD014242, 2010.

Worden, H. M., Edwards, D. P., Deeter, M. N., Fu, D., Kulawik, S. S., Worden, J. R., and Arellano, A.: Averaging kernel prediction from atmospheric and surface state parameters based on multiple regression for nadir-viewing satellite measurements of carbon monoxide and ozone, Atmos. Meas. Tech., 6, 1633-1646, doi:10.5194/amt-6-1633-2013, 2013.

Worden, H. M., Deeter, M. N., Edwards, D. P., Gille, J., Drummond, J., Emmons, L. K., Francis, G., Martínez-Alonso, S.: 13 years of MOPITT operations: lessons from MOPITT retrieval algorithm development, Ann. Geophys., 56, doi:10.4401/ag-6330, 2014.

Yoshida, Y., Kikuchi, N., Morino, I., Uchino, O., Oshchepkov, S., Bril, A., Saeki, T., Schutgens, N., Toon, G. C., Wunch, D., Roehl, C. M., Wennberg, P. O., Griffith, D. W. T., Deutscher, N. M., Warneke, T., Notholt, J., Robinson, J., Sherlock, V., Connor, B., Rettinger, M., Sussmann, R., Ahonen, P., Heikkinen, P., Kyrö, E., Mendonca, J., Strong, K., Hase, F., Dohe, S., and Yokota, T.: Improvement of the retrieval algorithm for GOSAT SWIR $\mathrm{XCO}_{2}$ and $\mathrm{XCH}_{4}$ and their validation using TCCON data, Atmos. Meas. Tech., 6, 1533-1547, doi:10.5194/amt-6-1533-2013, 2013. 